\title{
PERANAN ORGANISASI TERHADAP PRILAKU INDIVIDU, DISIPLIN DAN MOTIVASI YANG BERDAMPAK MEMBANGUN KINERJA
}

\section{THE ORGANIZATIONAL ROLE OF INDIVIDUAL BEHAVIOR, DISCIPLINE AND MOTIVATION THAT ARE IMPACTED TO BUILD PERFORMANCE}

\author{
Muhammad Idris. D.M \\ Universitas Maritim Raja Ali Haji, Tanjungpinang \\ Email : midrisdm@yahoo.com
}

\begin{abstract}
ABSTRAK
IImu tentang perilaku, disiplin, motivasi tentunya tidak terlepas dari teori-teori yang melandasinya. Terdapat beberapa teori perilaku, disiplin dan motivasi, yang memusatkan perhatian pada faktorfaktor individu yang mendorong, mengarahkan, mempertahankan, dan menghentikan perilaku, mereka mencoba menentukan kebutuhan-kebutuhan spesifik yang dapat memotivasi orang. Teori ini memusatkan diri pada kebutuhan individu dalam menjelaskan kepuasan kerja, perilaku kerja dan sistem imbalan. Selanjutnya teori ini menjelaskan bahwa efesiensi kebutuhan di dalam diri individu memicu semua respon perilaku bagi para pemimpin maupun manajer, agar menjadi efektif. Perilaku organisasi juga dikenal sebagai studi tentang organisasi. Studi ini adalah sebuah bidang akademik khusus yang mempelajari organisasi, maka dengan memanfaatkan metode dari ekonomi, sosiologi, ilmu politik, antropologi dan psikologi. Disiplin lain yang terkait dengan studi ini adalah studi tentang sumber daya manusia dan psikologi industri serta perilaku organisasi.
\end{abstract}

Kata Kunci : Peranan organisasi, prilaku individu, disiplin, motivasi dan kinerja

\begin{abstract}
The Knowledge of behavior, discipline, motivation certainly cannot be separated from the underlying theories. There are several theories of behavior, discipline and motivation, which focus on individual factors that encourage, direct, maintain, and stop behavior, they try to determine specific needs that can motivate people. This theory focuses on individual needs in explaining job satisfaction, work behavior and reward systems. Furthermore, this theory explains that the efficiency of needs in individuals triggers all behavioral responses for leaders and managers to be effective. Organizational behavior is also known as the study of organizations. This study is a special academic field that studies organizations, by utilizing methods from economics, sociology, political science, anthropology and psychology. Another discipline related to this study is the study of human resources and industrial psychology and organizational behavior.
\end{abstract}

Keywords : Organizational role, individual behavior, discipline, motivation and performance 


\section{PENDAHULUAN}

Studi organisasi adalah telaah tentang pribadi dan dinamika kelompok dan konteks organisasi, serta sifat organisasi itu sendiri. Setiap kali orang berinteraksi dalam organisasi, banyak faktor yang ikut bermain. Studi organisasi berusaha untuk memahami dan menyusun model-model dari faktor-faktor ini.

Seperti halnya dengan semua ilmu sosial, perilaku organisasi berusaha untuk mengontrol, memprediksikan, dan menjelaskan. Namun ada sejumlah kontroversi mengenai dampak etis dari pemusatan perhatian terhadap perilaku pekerja. Karena itu, perilaku organisasi (dan studi yang berdekatan dengannya, yaitu psikologi industri) kadang-kadang dituduh telah menjadi alat ilmiah bagi pihak yang berkuasa. Terlepas dari tuduhan-tuduhan itu, Perilaku Organisasi dapat memainkan peranan penting dalam perkembangan organisasi dan keberhasilan kerja.

Pengertian dari Ruang lingkup adalah Batasan. Ruang lingkup juga dapat dikemukakan pada bagian variabel-variabel yang diteliti, populasi atau subjek penelitian, dan lokasi penelitian. Penggambaran Ruang lingkup Dapat Kita Nilai Dari data karakteristik responden perlu dilakukan untuk memperoleh gambaran yang komprehensif tentang bagaimana keadaan responden penelitian kita, yang boleh jadi diperlukan untuk melihat data hasil pengukuran variabel-variabel yang diteliti.

Organisasi berasal dari kata organon dalam bahasa yunani yang berarti alat. Pengertian organisasi telah banyak disampaikan para ahli, tetapi pada dasarnya tidak ada perbedaan yang prinsip dan sebagai bahan perbandingan akan disampaikan beberapa pendapat antara ain : (1) Chester I Barnard mengemukakan bahwa organisasi adalah sistem kerja sama antara dua orang atau lebih, (2) James D. Mooney, mengatakan bahwa organisasi adalah setiap bentuk kerja sama untuk mencapai tujuan bersama.

Dari teori para ahli di atas bisa di sampaikan bahwa organiasi adalah kumpulan beberapa individu yang bekerja sama untuk mencapai suatu tujuan. Tiga unsur utama dalam suatu organisasi, yaitu: Organisasi memiliki kegunaan atau tujuan, pencapaian tujuan yang sudah di tetapkan, terdiri dari sekelompok manusia dan merupakan wadah sekelompok orang untuk bekerja sama.

Pengertian ruang lingkup perilaku organisasi adalah suatu batasan bidang studi yang dapat mempengaruhi individu,kelompok,dan struktur terhadap perilaku dalam organisasi yang bertujuan menerapkan ilmu pengetahuan guna meningkatkan keefektifan suatu organisasi,batasan bidang studi yang dimaksud seperti suatu keahlian oleh individu atau kelompok di bidang tertentu antara liain ; (1) Keahlian tekhnis (technical skills) meliputi kemampuan untuk menerapkan keahlian khusus seperti insinyur tehknik sipil atau ahli bedah mulut, (2) Keahlian personal (human skills) yaitu kemampuan untuk bekerja sama,memahami dan memotvasi individu lain,baik secara individual maupun secara kelompok.keahlian ini berguna untuk berkomunikasi,memotivasi,dan mendelegasikan perannya dalam organisasi, (3) Keahlian konseptual (conceptual skills) yaitu suatu kamampuan yang harus dimiliki oleh para manajer dalam mengatasi masalah-masalah yang rumit seperti pembuatan keputusan mulai dari mengidentifikasi masalah, mengembangkan solusi alternatif,mangevaluasi solusi-solusi alternatif dan memilih splusi yang terbaik. 
Sumber Daya Manusia (SDM) adalah faktor sentral dalam organisasi. Apapun bentuk serta tujuannya, organisasi dibuat berdasarkan berbagai visi untuk kepentingan manusia dan dalam pelaksanaan misinya dikelola dan diurus oleh manusiaUntuk itu Sumber Daya Manusia perlu dikembangkan dan diperhatikan agar kualitas Sumber Daya Manusia tersebut dapat ditingkatkan, sehingga berdampak pada meningkatnya kinerja organisasi (perusahaan) dimana Sumber Daya Manusia tersebut berada. Sumber Daya Manusia yang profesional dan berkualitas akan membentuk kinerja karyawan, baik individu maupun kelompok yang tinggi yang kemudian berdampak pada efektifitas organisasi secara keseluruhan. Persoalannya adalah bagaimana dapat menciptakan Sumber Daya Manusia yang dapat menghasilkan kinerja yang optimal sehingga tujuan perusahaan dapat tercapai. Membahas tentang kinerja karyawan tidak akan terlepas dengan adanya faktor-faktor yang dapat mempengaruhi kinerja seseorang. Mengingat permasalahan sangat kompleks, maka pihak-pihak yang terlibat dalam perusahaan harus cermat dalam mengamati sumber daya yang ada. Budaya organisasi dan motivasi merupakan bagian dari faktor-faktor yang dapat mempengaruhi terciptanya kinerja karyawan.

Motivasi karyawan yang rendah dan disiplin kurang baik, dapat mengakibatkan rendahnya kinerja karyawan yang ada dalam perusahaan. Motivasi karyawan dalam organisasi sangat penting, karena motivasi yang rendah dapat mempengaruhi kinerja yang rendah pula. Hal ini akan meningkatkan produktivitas karyawan sehingga berpengaruh pada pencapaian tujuan perusahaan. Sumber motivasi ada tiga faktor, yakni (1) kemungkinan untuk berkembang, (2) jenis pekerjaan, (3) apakah mereka akan merasa bangga menjadi bagian dari perusahaan tempat mereka bekerja (Rivai, 2004: 456).

\section{LANDASAN TEORI}

Menurut Stephen Robins (2007,p9), perilaku organisasi adalah suatu bidang studi yang menyelidiki dampak perorangan, kelompok dan struktur pada perilaku alam organisasi dengan maksud menerapkan pengetahuan untuk memperbaiki keefektifan organisasi. Perilaku organisasi mempelajari tiga pendekatan perilaku yakni perorangan, kelompok dan struktur. Dari pernyataan di atas, perilaku organisasi dapat didefinisikan sebagai studi mengenai apa yangdilakukan orang-orang dalam suatu organisasi dan bagaimana perilaku yang mempengaruhi kinerja dari organisasi tersebut. Perilaku organisasi merupakan ilmu perilaku terapan yang dibangun dan dikontribusikan dari sejumlah bidang perilaku disiplin. Bidangnya adalah Psikologi,Sosiologi, Psikologi Sosial, Antropologi. Kontribusi Psikologi terutama pada tingkatindividu atau mikro. Ketiga disiplin yang lain mengkontribusi pemahaman terhadapmakro.

Apabila kita melihat pemnbicaraan tentang perilaku disiplin, motivasi tentunya tidak terlepas dari teori-teori yang melandasinya . Terdapat beberapa teori perilaku,disiplindan motivasi, yang pada dasarnya dikelompokkan menjadi dua kelompok yaitu:

Pada dasarnya teori kepuasan memusatkan perhatian pada faktorfaktor individu yang mendorong, mengarahkan, mempertahankan, dan menghentikan perilaku. Mereka mencoba menentukan kebutuhankebutuhan spesifik yang memotivasi orang. Teori ini memusatkan diri pada kebutuhan individu didalam menjelaskan puasan kerja, perilaku kerja dan sistem imbalan. Selanjutnya teori ini menjelaskan bahwa efesiensi kebutuhan di dalam diri individu memicu semua respon perilaku bagipara pemimpin maupun manajer, agar menjadi efektif. 
Beberapa tokoh yang terkenal dengan teori ini adalah: (1) Teori Hirarki Kebutuhan dari Abraham Maslow, (2) Teori ERG Alderfer, (3) Teori Dua Faktor Herzberg dan (4) Teori Kebutuhan McClelland, (5) Teori $X$ dan Teori Y dari Douglas McGrego

Lebih menekankan pada usaha untuk lebih memberikan jawaban atas pertanyaan bagaimana bawahan bisa dimotivasi dan dengan tujuan apa bawahan bisa dimotivasi. Atau dengan kata lain teori proses ini menerangkan dan menganalisis bagaimana perilaku didorong, diarahkan, dipertahankan dan dihentikan.

Beberapa tokoh terkenal yang mengemukakan teori ini adalah (1)Vroom dengan teori pengharapan pilihan (2) Skiner dengan teori penguatan yang memperhatikan proses belajar yang terjadi sebagai konsekuensi perilaku (3) Adams dengan teori keadilan berdasarkan perbandingan yang dibuat individu (4) Locke dengan teori penetapan tujuan yang menganggap tujuan dan keinginan disadari merupakan faktor penentu perilaku.

Perilaku Organisasi adalah sebuah bidang studi yang menyelidiki pengaruh yang dimiliki individu, kelompok, dan sttruktur terhadap perilaku dalam organisasi, yang bertujuan menerapkan ilmu pengetahuan semacam ini guna meningkatkan keepektifan suatu organisasi.

Pengertian dari Ruang lingkup adalah Batasan. Ruang lingkup juga dapat dikemukakan pada bagian variabel-variabel yang diteliti, populasi atau subjek penelitian, dan lokasi penelitian. Penggambaran Ruang lingkup Dapat Kita Nilai Dari data karakteristik responden perlu dilakukan untuk memperoleh gambaran yang komprehensif tentang bagaimana keadaan responden penelitian kita, yang boleh jadi diperlukan untuk melihat data hasil pengukuran variabel-variabel yang diteliti.

Pengertian ruang lingkup perilaku organisasi adalah suatu batasan bidang studi yang dapat mempengaruhi individu,kelompok,dan struktur terhadap perilaku dalam organisasi yang bertujuan menerapkan ilmu pengetahuan guna meningkatkan keefektifan suatu organisasi,batasan bidang studi yang dimaksud seperti suatu keahlian oleh individu atau kelompok di bidang tertentu, antala lain : (1) Keahlian tekhnis (technical skills) meliputi kemampuan untuk menerapkan keahlian khusus seperti insinyur tehknik sipil atau ahli bedah mulut, (2) Keahlian personal (human skills) yaitu kemampuan untuk bekerja sama,memahami dan memotvasi individu lain,baik secara individual maupun secara kelompok.keahlian ini berguna untuk berkomunikasi,memotivasi,dan mendelegasikan perannya dalam organisasi, (3) keahlian konseptual (conceptual skills) yaitu suatu kamampuan yang harus dimiliki oleh para manajer dalam mengatasi masalah-masalah yang rumit seperti pembuatan keputusan mulai dari mengidentifikasi masalah,mengembangkan solusi alternatif,mangevaluasi solusi-solusi alternatif dan memilih splusi yang terbaik

Mungkin bisa dikatakan bahwa teori motivasi yang paling terkenal adalah hirarki kebutuhan yang diungkapkan Abraham Maslow. Hipotesisnya mengatakan bahwa didalam diri semua manusia bersemayam lima jenjang kebutuhan yaitu :

a) Psikologis, antara lain: rasa lapar haus, perlindungan (pakaian dan perumahan), seks dan kebutuhan jasmani lainnya

b) Keamanan, antara lain keselamatan dan perlindungan terhadap kerugian fisik dan emosional.

c) Sosial, mencakup kasih sayang, rasa memiliki, diterima baik dan persahabatan.

d) Penghargaan, mencakup factor penghormatan diri seperti harga diri, otonomi, dan prestasi, serta faktor penghormatan dari luar seperti misalnya status, pengakuan dan perhatian. 
e) Aktualisasi diri, dorongan untuk menjadi seseorang atau sesuatu sesuai ambisinya yang mencakup pertumbuhan, pencapai potensi dan pemenuhan kebutuhan diri.

Menurut Joe.Kelly, perilaku organisasi adalah suatu bidang studi yang mempelajari sifat-sifat organisasi, termasuk bagaimana organisasi di bentuk, tumbuh dan berkembang, sedangkan menurut Adam Indrawijaya, perilaku organisasi adalah suatu bidang studi yang mempelajari semua aspek yang berkaitan dengan tindakan manusia, baik aspek pengaruh anggota terhadap organisasi maupun pengaruh organisasi terhadap anggota. Sutrisna Hari perilaku organisasi adalah suatu bidang studi yang mempelajari dinamika organisasi sebagai hasil interaksi dari sifat khusus (karakteristik) anggota dan sifat khusus (karakteristik) para anggotannya dan pengaruh lingkungan

Perilaku Organisasi adalah bidang studi yang menyelidiki dampak perorangan, kelompok, dan struktur pada perilaku dalam organisasi dengan maksud menerapkan pengetahuan semacam itu untuk memperbaiki keefektifan organisasi.

Motivasi merupakan salah satu faktor yang juga memiliki peranan yang sangat penting dalam peningkatan produktivitas dan kinerja karyawan. Hal ini didasarkan pada asumsi : pertama individu mempunyai kesadaran yang bervariasi, tujuan yang kompleks serta perasaan bersaing, kedua sebagian besar perilaku individu dilakukan dengan sadar dan mengarah pada tujuan dan ketiga individu memberikan reaksi, penilaian serta perasaan terhadap hasil perilakunya (Lawer 1994:3), Robins (2006:214), mendefenisikan motivasi sebagai proses yang berperan pada intensitas, arah, dan lamanya berlangsung upaya individu kearah pencapaian sasaran. Intensitas terkait dengan seberapa keras seseorang berusaha.Berbicara mengenai motivasi tentunya tidak terlepas dari teori-teori yang melandasi motivasi itu sendiri. Terdapat beberapa teori motivasi.

\section{Teori Kepuasan}

Pada dasarnya teori kepuasan memusatkan perhatian pada faktorfaktor individu yang mendorong, mengarahkan, mempertahankan, dan menghentikan perilaku. Mereka mencoba menentukan kebutuhankebutuhan spesifik yang memotivasi orang. Teori ini memusatkan diri pada kebutuhan individu didalam menjelaskan kepuasan kerja, perilaku kerja dan sistem imbalan. Selanjutnya teori ini menjelaskan bahwa efesiensi kebutuhan di dalam diri individu memicu semua respon perilaku bagipara pemimpin maupun manajer, agar menjadi efektif.

Beberapa tokoh yang terkenal dengan teori ini adalah: (1) Teori Hirarki Kebutuhan dari Abraham Maslow, (2) Teori ERG Alderfer, (3) Teori Dua Faktor Herzberg dan (4) Teori Kebutuhan McClelland, (5) Teori X dan Teori Y dari Douglas McGrego

\section{Teori Proses}

Lebih menekankan pada usaha untuk lebih memberikan jawaban atas pertanyaan bagaimana bawahan bisa dimotivasi dan dengan tujuan apa bawahan bisa dimotivasi. Atau dengan kata lain teori proses ini menerangkan dan menganalisis bagaimana perilaku didorong, diarahkan, dipertahankan dan dihentikan.

Beberapa tokoh terkenal yang mengemukakan teori ini adalah (1)Vroom dengan teori pengharapan pilihan (2) Skiner dengan teori penguatan yang memperhatikan proses belajar yang terjadi sebagai konsekuensi perilaku (3) Adams dengan teori keadilan berdasarkan perbandingan 
yang dibuat individu (4) Locke dengan teori penetapan tujuan yang menganggap tujuan dan keinginan disadari merupakan faktor penentu perilaku.

\section{Teori Hirarki Kebutuhan}

Mungkin bisa dikatakan bahwa teori motivasi yang paling terkenal adalah hirarki kebutuhan yang diungkapkan Abraham Maslow. Hipotesisnya mengatakan bahwa didalam diri semua manusia bersemayam lima jenjang kebutuhan yaitu sebagi berikut:

1) Psikologis, antara lain: rasa lapar haus, perlindungan (pakaian dan perumahan), seks dan kebutuhan jasmani lainnya.

2) Keamanan, antara lain keselamatan dan perlindungan terhadap kerugian fisik dan emosional.

3) Sosial, mencakup kasih sayang, rasa memiliki, diterima baik dan persahabatan.

4) Penghargaan, mencakup factor penghormatan diri seperti harga diri, otonomi, dan prestasi, serta faktor penghormatan dari luar seperti misalnya status, pengakuan dan perhatian.

5) Aktualisasi diri, dorongan untuk menjadi seseorang atau sesuatu sesuai ambisinya yang mencakup pertumbuhan, pencapai potensi dan pemenuhan kebutuhan diri.

\section{Teori $\mathrm{X}$ dan Teori $\mathrm{Y}$}

Douglas McGregor dua pandangan yang jelas berbeda mengenai manusia. Pada dasarnya yang satu negatif, yang ditandai dengan teori $X$ dan yang lain positif yang ditandai dengan teori $Y$.

Menurut teori $\mathrm{X}$, empat asumsi yang dipegang para manajer adalah sebagai berikut:

1) Karyawan secara inheren tidak menyukai kerja dan bila dimungkinkan akan mencoba menghindarinya.

2) Karyawan tidak menyukai kerja , mereka harus dipaksa, diawasi, atau diancam dengan hukuman untuk mencapai sasaran.

3) Karyawan akan menghindari tangg

4) ungjawab dan mencari penghargaan formal bila mungkin.

5) Kebanyakan karyawan menempatkan keamanan diatas semua faktor lain yang terkait dengan kerja dan akan menunjukan ambisi yang rendah.

Kontras dengan pandangan negatif mengenai kodrat manusia ini McGregor mencatat empat asumsi positif yang disebut teori $Y$ :

1) Karyawan dapat memandang kerja sebagai kegiatan alami yang sama dengan istirahat atau bermain.

2) Orang-orang akan melakukan penghargaan diri dan pengawasan diri jika mereka memiliki komitmen pada sasaran.

3) Rata-rata orang dapat belajar untuk menerima, bahkan mengusahakan tanggungjawab.

4) Kemampuan untuk mengambil inovatif menyebar luas kesemua orang dan tidak hanya milik mereka yang berada dalam posisi manajemen. 


\section{Teori Dua Faktor}

Herzberg berpendapat bahwa apabila para manajer ingin memberikan motivasi kepada para bawahannya, yang perlu ditekankan adalah faktor-faktor yang menimbulkan rasa puas yaitu dengan mengutamakan faktor motivasional yang sifat intrisik. (Siagian 1995:165)

Tabel 1. Teori Dua Faktor Herzberg

\begin{tabular}{ll}
\hline Faktor-Faktor Higienis & Motivator \\
\hline 1. Kebijakan dan administrasi perusahaan & 1. Prestasi \\
2. Pengawasan teknis & 2. Pengakuan,penghargaan \\
3. Gaji & 3. Pekerjaan itu sendiri \\
4. Hubungan antar pribadi, penyila & 4. Tanggung jawab \\
5. Kondisi kerja & 5. Promosi \\
\hline
\end{tabular}

Kerangka dasar pada perilaku organisasi adalah terletak pada dua komponen yaitu individu-individu yang berperilaku, baik itu perilaku secara individu, perilaku kelompok, dan perilaku organisasi. Komponen yang kedua adalah organisasi formal sebagai wadah dari perilaku itu. Yaitu sebagai sarana bagi ndividu dalam bermasyarakat ditandai dengan keterlibatannya pada suatu organisasi. Dan, menjalankan perannya dalam organisasi tersebut. Pengertian perilaku organisasi menurut beberapa ahli

Pada umumnya setiap individu memiliki suatu kebutuhan hidup, mulai dari yang sederhana(primer) sampai kebutuhan yang lebih/luas(tersier). Karena untuk memenuhi kebutuhannya, setiap individu memerlukan suatu tempat untuk memenuhi kebutuhannya. Maka

Manusia adalah makhluk yang rumit. Karena tidak serupa, kemampuan manusia untuk membuat generalisasi yang sederhana, akurat, dan luas sangat terbatas. Konsep-konsep Perilaku Organisasi mencerminkan kondisi-kondisi yang situasionalatau mempunyai banyak kemungkinan. IImu PengetahuanPerilaku Industri dikembangkan dengan cara mengambil konsep-konsep umum dan menerapkannya dalam situasi, individu, atau kelompok tertentu.

Individu menyukai yang rumit, dengan kata lain seorang menyukai perkerjaan itu dan yang lain belum tentu.Dari itu, manusia memerlukan organisasi untuk pemenuhan kebutuhan hidupnya. Baik itu organisasi di bidang pendidikan, hobi, pekerjaan, dan lain - lain. Dalam perilaku organisasi dijelaskan bagaimana perbedaan kebutuhan antar individu, karakter karakter setiap individu, dan komunikasi antar individu yang berpengaruh dalam pencapain tujuan itu.

Kedisiplinanmerupakanfungsioperasionalmanajemensumberdayamanusia yang terpenting karena semakin baik disiplin kerja pegawai, semakin baik kinerja yang dapat dicapai. Tanpa disiplin yang baik, sulit bagi organisasi untuk mencapai hasil yang optimal. Kedisiplinan merupakan faktor yang utama yang diperlukan sebagai alat peringatan terhadap pegawai yang tidak mau berubah sifat dan perilakunya. Sehingga seorang pegawai dikatakan memiliki disiplin 
yang baik jika pegawai tersebut memiliki rasa tanggungjawab terhadap tugas yang diberikan kepadanya.

Nilai mencerminkan perilaku dasar bahwa bentuk khusus perilaku atau bentuk akhir keberadaan secara peribadi atau social lebih dipilih dibandingkan dengan bentuk perilaku atau bentuk akhir keberadaan perlawanan atau kebalikan. Nilai sangat penting untuk mempelajari perilaku organisasi karena nilai menjadi dasar untuk memahami sikap dan motivasi serta memahami persepsi kita, individu memasuki organisasi berdasarkan yang dikonsefkan sebelumnya mengenai apa yang seharusnya dan apa yang tidak seharusnya.

\section{HASIL DAN PEMBAHASAN}

Perilaku organisasi sangat penting digunakan dalam ruang lingkup keorganisasian karena perilaku organisasi dapat mengetahui karakter para pelakunya. Perilaku organisasi merupakan suatu ilmu yang mempelajari tentang perilaku individu dalam kelompok organisasi yang berhubungan langsung dengan ilmu - ilmu yang lainnya. Organisasi merupakan suatu tempat berkumpulnya sekelompok orang yang memilki tujuan bersama, memilki eksistensi dalam pencapainnya. Maka dari itu, perilaku organisasi sangat berguna bagi para pelakuo organisasi untuk mengetahui sifat-sifat/karakter apa saja yang dibutuhkan dalam berperilaku di organisasi.

Motivasi yang tidak di ikuti dengan disiplin yang baik terhadap peningkatan kinerja akan memuat lemahnya oragnisasi. sebelum membahas kinerja tentunya kita harus memikirkan bagaimana seorang pegawai termotivasi untuk belajar sehingga nantinya berpengaruh pada peninggkatan kinerjanya menjadi lebih baik. Training sebagai salah satu cara untuk belajar harus dapat dimanfaatkan sebagai cara untuk meningkatkan kompetensi sehingga meningkatkan motivasi pegawai untuk berkinerja lebih baik pada perusahaan. Oleh karena itu training harus dirancang sedemikian rupa guna meningkatkanmotivasi pegawai.

1) Relevan.Pegawai akan termotivasi untuk belajar jika meteri yang disampaikan pada pelatihan relevan bagi mereka, sehingga meraka dapat mengaitkan dengan kebutuhan nya untuk berkinerja lebih baik.

2) Mengguntungkan Pegawai akan lebih termotivasi untuk belajar jika mereka mengetahui bahwa pelatihan tersebut mengguntungkan bagi mereka. Dalam hal ini perlu dikaitkan antara pelatihan tersebut dengan dampaknya bagi peningkatan kinerja.

3) Menarik.Pegawai akan lebih termotivasi untuk belajar jika pelatihan itu menarik, jadi perlu menggunakan metode yang dapat membuat proses pembelajaran menjadi lebih menarik.

Jadi sangatlah jelas bahwa peran motivasi sangatlah tingginpengaruhnya terthadap kinerja seseorang. Apabila pegawai telah memiliki motivasi untuk belajar diharapkan ia pun memiliki motivasi yang tinggi untuk bekerja dam memberikan kontribusi terbaiknya bagi perusahaan.dan semuanya ini harus di ikuti dengan disiplin yang tinggi agar dapat membangun kinerja yang baik bagi setiap karyawan /pegawai.

Jika tiap individu berperilaku atau bekerja efektif dalam mencapai tujuannya, maka kelompok dimana ia menjadi anggota, juga menjadi efektif dalam mencapai tujuan, jika tiap-tiap kelompok dalam organisasi juga efektif dalam mencapai tujuan, maka organisasi juga akan menjadi efektif dalam mencapai tujuan organisasi.

Dalam mengelola organisasi, berbagai pandangan atau disiplin ilmu digunakan bersama untuk membentuk suatu satuan yang disebut disiplin perilaku organisasional. Pendekatan yang 
sering dipergunakan untuk memahami perilaku manusia adalah; pendekatan kognitif, reinforcement, dan psikoanalitis.

\section{REKOMENDASI DAN KEBIJAKAN}

\section{Rekomendasi}

Berdasarkan hasil dan pembahasan penelitian yang diuraikan oleh penelitia dalam penelitian ini, maka kesimpulan penelitian terdiri dari :

1. Manajer harus mengembangkan keahlian antar personal atau personal mereka jika ingin memperoleh keefektifan dalam pekerjaan.

2. Perilaku organisasi mencapai tingkat kecanggihan tertingginya ketika kita menambahkan sistem organisasi formal kedalam pengetahuan kita tentang perilaku individu dan kelompok.

3. Perilaku organisasi menerapkan ilmu pengetahuan yang di peroleh tentang individu,kelompok,dan pengaruh dari struktur terhadap perilaku untuk membuat organisasi bekerja secara lebih efektif .

4. Pada tingkat individu, jika pegawai merasa bahwa organisasi memenuhi kebutuhan dan karakteristik individualnya, ia akan cenderung berperilaku positif. Tetapi sebaliknya, jika pegawai tidak merasa diperlakukan dengan adil, maka mereka cenderung akan menurunnya disiplin pegawai.

5. setiap individu mempunyai karakteristik yang berbeda, karena mereka mempunyai kebutuhan yang berbeda pula. Kebutuhan - kebutuhan tersebut yang membuat mereka termotivasi untuk melakukan pekerjaan tersebut lebih baik, baik dari dirinya sendiri maupun orang lain. Dalam diri individu, terdapat perilaku perilaku yang betentangan kebijakan.. Disini dibutuhkan pendekatan - pendekatan yang dapat memodifikasi perilaku yang tidak baik menjadi baik. Apabila pendekatan tersebut berhasil, bisa dilihat dari kinerja seseorang, kualitas pekerjaan, tingkat kehladiran dan tingkat keluar masuknya seseorang dalam organisasi. Diharapkan sesama orang dalam organisasi bisa memotivasi yang lainnya agar tujuan yang ingin dicapai bisa terlaksana dengan baik sesuai dengan kemampuan yang ada. Apabila ada kekurangan atau masalah segeralah berunding dengan sesama dan evaluasi apa saja yang telah dlakukan agar ke depannya bisa menjadi lebih baik.

6. Aktifitas-aktifitas para manejerial menunjukkan aktifitas yang baik agari para karyawan bawahan mengikuti perilaku atasanya tersebut namun seorang manajer juga harus peduli terhadap kuantitas dan kualitas output yang dihasilkan oleh setiap karyawan artinya bahwa seorang manejer memiliki tanggung jawab kemanusian untuk memberi pekerjaan yang menantang,penghargaan dan kepuasan terhadap karyawan mereka.

7. Di dalam sekelompok orang yang mempunyai hubungan keterkaitan antara satu dengan lainnya sehingga bersosialisasi dengan para pelaku organisasi. Maka perilaku organisasi, individu individu yang mempunyai motivasi kerja dan disiplin yang tinggi maka harus mampu menyesuaikan dirinya dengan bersosialisasi dengan yang lain. Ini akan membuat tugas yang telah diberikan akan terasa mudah karena tugas tersebut bisa dilakukan secara bersama sama. Karena setiap orang mempunyai kebutuhan, maka sebaiknya dalam berperilaku organisasi seseorang mampu bereksistensi dengan orang lain agar mampu melaksanakan tujuan yang ingin dicapai. 


\section{DAFTAR PUSTAKA}

Boediono, 1999. "Strategi Pemberdayaan SDM dalam Masyarakat Global", Bapenas (Materi seminar Tidak dipublikasikan) Jakarta

Davi S, Keith \& John W Newstrom. 1996. Perilaku dalam organisasi. Jakarta : Erlangga Kelompok GRAMEDIA. Jakarta

Lase, Jason.2001. "Prestasi Kerja Pejabat". Desertasi (Sinopsi). Fakultas Pascasarjana UNJ Jakarta.

Napitupulu, Dongsina. 2001. "Evaluasi diri tentang Kinerja Guru". Desertasi Sinopsis), Fakultas Pascasarjana UNJ Jakarta.

Prijodarminto, Soegeng. 1994. Disiplin kiat menuju sukses. Jakarta : Abadi

Randal S.S \& Susan E.J, 1997. " Manajemen Sumber Daya Manusia" Penerbit Erlangga. Jakarta

Rivai, Veithzal, \& Ahmad Fauwzi Mohd. Basri 2005 "Performamce Appraisal" Jakarta, PT. Raja grapindo Persada.

Robbins, Stephen P. - Timothy A. Jugde, 2007, Perilaku Organisasi” Jakarta, Salemba Empat.

Robbins, Stephen. P. 2006. Perilaku organisasi.Edisi Bahasa Indonesia. PT Indeks

Sondang P. Siagian, 1995 . "Teori Motivasi dan Aplikasi" buku 1, Penerbit Rineka Cipta. Jakarta

Sulaiman, Dadang. 1988. Teknologi / Metodologi Penelitian. Jakarta: Depdikbud RI. Dirjen Dikti

Sule, Ernie Tisnawati \& Kurniawan Saefullah, 2005. "Pengantar Manajemen". Edisi Pertama. Penerbit Kencana. Jakarta

Sutisna, Oteng. tth Administrasi Dasar teoritis untuk praktek Profesional. Bandung : Angkasa.

Tharbany, Hasbullah. 1995. Rahasia Sukses belajar. Jakarta : Raja Grafindo Persada

Wursanto, I. C.. 1992. Manajemen Kepegawaian, Yogyakarta : Kainsius

http://agungpia.multiply.com/journal/item/23/Dasar-dasar_Perilaku_Individu

http: //blogs.unpad.ac.id/nadiasabrina/

http://irasetiawati.wordpress.com/2009/04/30/kepribadian-individu-danperilakunya-dalamorganisasil

http://rikiseptiawan.blogspot.com/ 